\title{
Review Article \\ Potential Impacts of Climate Change on the Toxicity of Pesticides towards Earthworms
}

\author{
H. Kaka ${ }^{(D)},{ }^{1}$ P. A. Opute $\mathbb{D}^{1,2}$ and M. S. Maboeta ${ }^{1}{ }^{1}$ \\ ${ }^{1}$ Unit for Environmental Sciences and Management, North-West University, Private Bag X6001, Potchefstroom 2520, \\ South Africa \\ ${ }^{2}$ Department of Animal and Environmental Biology, Faculty of Life Sciences, University of Benin, Benin City, Nigeria
}

Correspondence should be addressed to M. S. Maboeta; mark.maboeta@nwu.ac.za

Received 21 April 2021; Revised 28 June 2021; Accepted 13 August 2021; Published 20 August 2021

Academic Editor: Massimo Moretti

Copyright (c) $2021 \mathrm{H}$. Kaka et al. This is an open access article distributed under the Creative Commons Attribution License, which permits unrestricted use, distribution, and reproduction in any medium, provided the original work is properly cited.

\begin{abstract}
This review examined one of the effects of climate change that has only recently received attention, i.e., climate change impacts on the distribution and toxicity of chemical contaminants in the environment. As ecosystem engineers, earthworms are potentially threatened by the increasing use of pesticides. Increases in temperature, precipitation regime changes, and related extreme climate events can potentially affect pesticide toxicity. This review of original research articles, reviews, and governmental and intergovernmental reports focused on the interactions between toxicants and environmental parameters. The latter included temperature, moisture, acidification, hypoxia, soil carbon cycle, and soil dynamics, as altered by climate change. Dynamic interactions between climate change and contaminants can be particularly problematic for organisms since organisms have an upper and lower physiological range, resulting in impacts on their acclimatization capacity. Climate change variables such as temperature and soil moisture also have an impact on acidification. An increase in temperature will impact precipitation which might impact soil $\mathrm{pH}$. Also, an increase in precipitation can result in flooding which can reduce the population of earthworms by not giving juvenile earthworms enough time to develop into reproductive adults. As an independent stressor, hypoxia can affect soil organisms, alter bioavailability, and increase the toxicity of chemicals in some cases. Climate change variables, especially temperature and soil moisture, significantly affect the bioavailability of pesticides in the soil and the growth and reproduction of earthworm species.
\end{abstract}

\section{Introduction}

Climate change is defined as the alteration in the climate state, evidenced by changes in the variability of its properties such as temperature, precipitation, and wind [1]. These variables persist for an extended period (typically decades or longer) which coincides with an increased likelihood in the intensity of extreme climate events, such as drought and flooding $[2,3]$. Soil biodiversity includes many different types of organisms ranging from microscopic organisms to large animals and plants. The soil supports a wide range of ecosystem functions, processes, and services, making it essential to human life [4-7]. At some point, environmental processes in the air, water, and soil interact with each other, and this interaction is essential for these processes to function at an optimal level. Anthropogenic activities including agricultural and mining activities are primarily responsible for soil pollution [8-10] which impacts the biodiversity of soil organisms which are therefore reduced or lost [11].

Earthworms make up $40-90 \%$ of the soil macrofaunal biomass in many terrestrial ecosystems and thus are vital soil organisms [3]. There are 23 families and over 700 genera with more than 7,000 species of earthworms already described worldwide, although the number of species is much more $[3,12]$. They play an important role as ecosystem engineers, thus making them keystone species [3]. The environment is modified physically and chemically by earthworms; they create, transform, and maintain the habitat for soil organisms and plant communities [5]. These modifications are done by processes such as litter fragmentation, burrowing, and casting activities. These activities 
drive soil processes such as nutrient cycling, soil aggregate stability, water infiltration, plant growth, and soil carbon storage [13]. They have many roles in the ecosystem, making them very useful as bioindicators in soil ecotoxicological studies [14-16]. The diversity of earthworm species is studied worldwide, and Phillips et al. [17] highlighted climate change drivers such as increasing air temperature and changing mean annual rainfall as key factors affecting its global distribution. Climate change alters soil properties such as moisture, temperature, $\mathrm{pH}$, and texture, affecting not only earthworm communities but also all life interacting with the soil environment [3].

\section{Predicted Global Change Scenarios}

Climate change is a global problem. Generally, when models are used to predict future changes in climate, it usually suggests an increase in more extreme and severe events in the coming decades [1]. The main drivers of climate change affecting the soil ecosystem are greenhouse gases, air and soil temperature increases, extreme precipitation, and erosion $[18,19]$. According to the Intergovernmental Panel on Climate Change [20], global warming for 2006-2015 was $0.87^{\circ} \mathrm{C}$, which is higher than the average between 1850 and 1900. The estimated global warming caused by anthropogenic activity is currently increasing at $0.2^{\circ} \mathrm{C}$ per decade due to the past and ongoing impact of pollutants [20]. Activities by humans have caused global warming to increase by $1^{\circ} \mathrm{C}$ above preindustrial levels, and this is likely to reach $1.5^{\circ} \mathrm{C}$ between 2030 and 2052 if it continues to increase at this current rate [20]. When comparing regional changes of the preindustrial levels to the $1.5^{\circ} \mathrm{C}$ increase in global warming, it estimates extreme increased temperatures, increased heavy precipitation, and an increase in drought in many regions, for example, the projected increase in precipitation in West Africa, the increase in temperature in the Indian Ocean resulting in increased rain in East Africa, and the increased global surface temperature [20]. These predicted climate change events may have significant effects on the bioavailability of pollutants in the soil.

The ability of greenhouse gases such as carbon dioxide, methane, nitrous oxide, and fluorinated gases to capture heat from the sun's energy causes the greenhouse effect [21]. The primary sources of air pollution are the combustion of fossil fuels, as well as industrial and agricultural activities. As a result of these events, more of the sun's radiation is trapped in the atmosphere, causing global warming (Figure 1). According to Olivier and Peters [22], since the year 2012, the global annual increase in $\mathrm{CO}_{2}$ emissions has slowed down to about $1.5 \%$, and in 2015-2016, it has remained flat. In 2017, 2018, and 2019, the global $\mathrm{CO}_{2}$ emissions increased by 1.4 , 2.4 , and $0.9 \%$, respectively. The increase was a result of increased consumption in coal. The annual global carbon sequestration potential is about $0.4-0.7 \mathrm{Pg} \mathrm{C} \mathrm{y}^{-1}$, which means that if these rates remain constant until the year 2100 , the soil carbon sequestration would only contribute to a maximum of $1-3 \%$ towards reducing the carbon emissions [23]. This scenario suggests that carbon sequestration into the soil will play a minimal role in reducing carbon dioxide emissions. The study conducted by Marhan et al. [24] indicated a higher loss of nitrogen in the form of $\mathrm{N}_{2} \mathrm{O}$ from the soil with high earthworm population and a warmer climate.

As shown in Figure 2, greenhouse gases are increasing at an alarming rate, and the increase has been exponential over the last \pm 60 years. If left unchecked, this extreme increase will keep on having a massive effect on environments worldwide. Human activity is responsible for the rapid rise in greenhouse gases such as carbon dioxide, methane, and nitrous oxide [25]. Most of the gas emitted is carbon dioxide, although gases such as methane and nitrous oxide are much better at absorbing infrared radiation and contributing to global warming [25]. Over 100 years, $1 \mathrm{~kg}$ of methane has a warming potential 23 times greater than $1 \mathrm{~kg}$ of carbon dioxide, and $1 \mathrm{~kg}$ of nitrous oxide has a warming potential of nearly 300 times that of carbon dioxide [25]. Approximately two-thirds of the nitrous oxide emissions and one-third of the atmosphere's methane emissions come from soils [25]. If global warming continues unabated, it can have many devastating effects such as rising sea levels, ocean acidification, and severe weather events. However, there have been international initiatives such as the Kyoto Protocol, the signing of the Paris Agreement on climate change, and other initiatives set up to combat this effect globally [21]. According to Olivier et al. [26], the record for the warmest year in 140 years was 2016 with an increase of $+0.99^{\circ} \mathrm{C}$, and in 2019, it was the second warmest year with the global land and ocean surface temperatures increasing by $+0.95^{\circ} \mathrm{C}$ above the average. They further stated that, since 1880, 9 out of the 10 warmest years have occurred since 2005 .

Anthropogenic activity has had an influence on the global water cycle and in turn affected the global precipitation regime by globally increasing the amount of atmospheric moisture and the precipitation patterns over the land [1]. Singh et al. [3] stated that precipitation regime changes might show significant heterogeneity and thus be difficult to predict. However, climate models project an increase in the frequency of extreme precipitation events. Also, an increase in rainfall due to climate change can result in soil loss and soil erosion by increasing sedimentation in streams and reservoirs [19]. This soil loss will have detrimental effects on soil organisms as well as soil functions in an ecosystem. Once these functions are disrupted, changes in the environment can occur. Most of water which supplies soil moisture comes in the form of precipitation and is evaporated from the ocean and transported to the land by the atmosphere, and this movement of water in a climate system is an essential part of life on land.

Ultraviolet radiation is one of the components of solar radiation, and it is separated into UV-A, UV-B, and UV-C [27]. Stratospheric ozone usually reflects UV-C and UV-B; thus, only UV-A and very little UV-B reach the Earth, although due to the depletion of atmospheric ozone, there is an increase in UV-B reaching the Earth [27, 28]. Higher UV$\mathrm{B}$ radiation modifies soil microbial communities and decreases populations of soil meso- and macrofauna [28]. According to Formánek et al. [28], UV-B is known to increase degradation of some pollutants such as phenylurea herbicides, p,p'-DDT, 2,4-dichlorophenoxyacetic acid, 


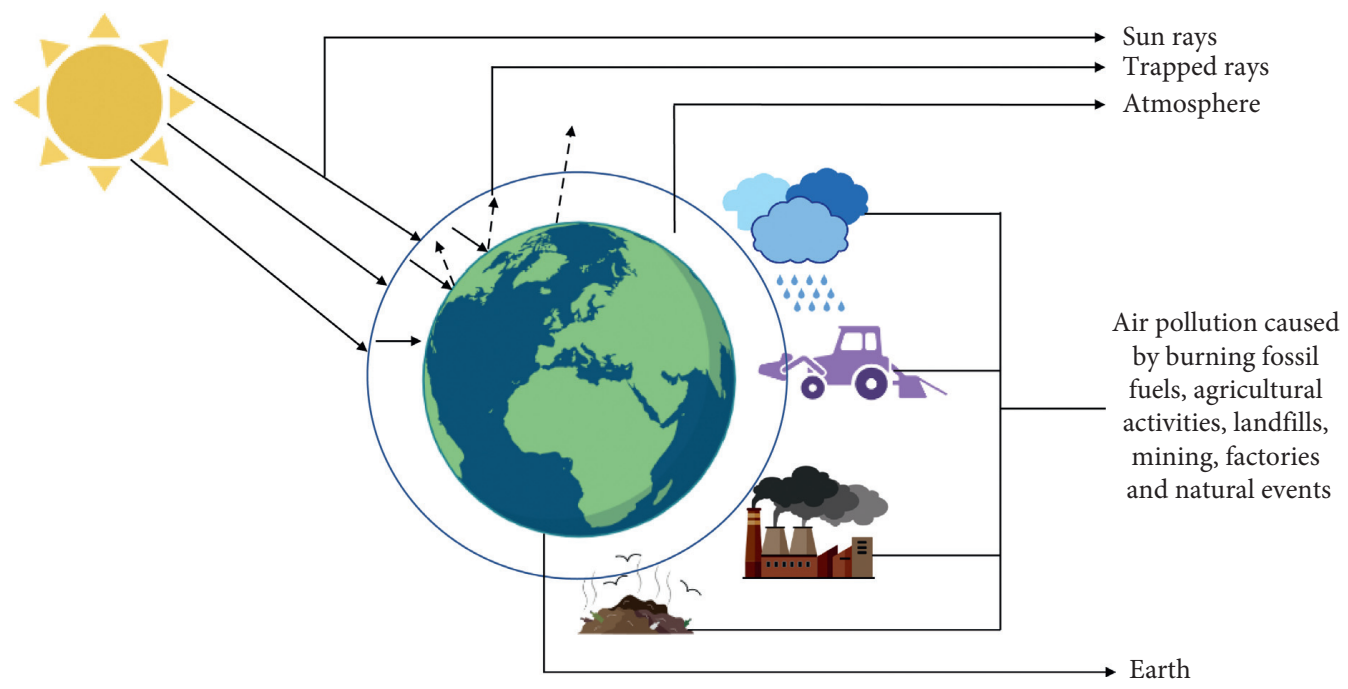

Figure 1: Simple representation of the greenhouse effect. The main drivers of air pollution: burning of fossil fuels and industrial and agricultural activities. These events trap more of the sun's radiation in the atmosphere resulting in global warming.

biphenol, and PAHs, although it can also inhibit rhizoremediation of organic pollutants. In arid and semiarid regions, ultraviolet radiation is one of the main drivers of increasing litter decay through photodegradation [29]. Abiotic photodegradation can mineralize the decomposition of litter into gases such as $\mathrm{CO}_{2}, \mathrm{CO}$, and $\mathrm{CH}_{4}$ and, at the same time, alter the chemistry of organic materials [29]. Complex carbon structures can be broken down by ultraviolet radiation into smaller molecular compounds, increasing dissolved organic carbon concentration in the litter [29].

\section{Consequences of Climate Change for the Structure and Function of Soil Ecosystems}

According to Bellard et al. [30], in fifty years from now, we are likely to see an increase in the rate of species loss due to climate change, although the evidence that this will happen is still inconclusive. The aboveground and belowground ecosystems have many interactions, and they rely on one another for specific functions [31]. However, the aboveground biodiversity is usually observed and acts as a basis for predicting environmental changes [32]. The need to study the biodiversity of aboveground and belowground ecosystems simultaneously is essential because we might not find the differences found in one ecosystem in the other [33]. Anthropogenic activities contribute to the loss of biodiversity and ecosystem services in soil. Mining and agriculture, for example, exploit the soil ecosystem in an unsustainable manner, potentially resulting in a $60 \%$ depletion of ecosystem services [7, 34]. Soils and soil processes will primarily be affected by climate change through changes in rainfall patterns and temperature. Earthworm populations will be affected by climate change variables such as drought, irregular precipitation, and increasing temperatures [35-37]. Additional research is required on climate change effects on soil organisms to develop and improve models [38]. Irrespective of the fact that earthworms and other soil organisms play a vital role in soil ecosystems and functions and the noticeable danger of climate change, there is still no conclusive overview of climate change effects on soil organisms, particularly earthworms, given the increasing pesticide pollution in the environment.

3.1. Rise in Soil Temperature. Temperature is one of the most important climate change drivers, and it is influential in determining soil biological activity and the decomposition process [3]. The increase in temperature has shown to be the cause of various alterations to many plant and animal species, with it being massively influenced by biotic interactions [39, 40]. Earthworms are a poikilothermic species, which means that their body temperatures fluctuate with their respective environments; therefore, the activity, density, growth, metabolism, respiration, and reproduction of earthworms are all affected by temperature variations. They tend to gather in areas where conditions are ideal for their metabolism, suggesting that both high and low temperatures produce a direct response; these effects include reduced growth rate, feeding activity, cocoon production, and juvenile development both at the individual and community level [3]. Although more is known about the higher lethal temperatures than the lower lethal temperatures, the response of earthworms to temperature fluctuations is also dependent on the species involved because every species has its specific tolerance range for different variables. The increase in temperature can also affect the bioavailability of the soil's metal pollutants. Besides the fact that temperature will influence soil organisms in the natural world, many other variables, such as the soil moisture content, will also affect the ecosystem at the same time.

A study conducted by Eggleton et al. [41] showed earthworm diversity over six years and took into account temperature and soil moisture as climate change variables. They reported a decrease in earthworm numbers in the dry winter months, and during the moist summer months, there 


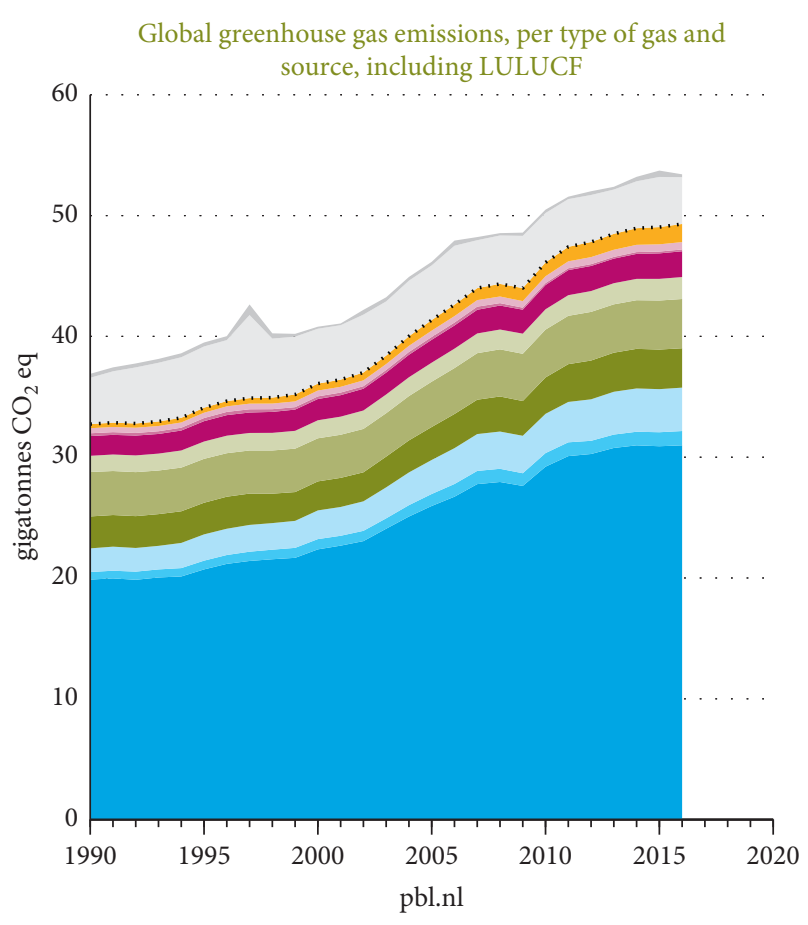

Land Use, Land-Use Change and Forestry (LULUCF)
Forest and peat fires $\left(\mathrm{N}_{2} \mathrm{O}\right.$ and $\left.\mathrm{CH}_{4}\right)$
Land-use change emissions $\left(\mathrm{CO}_{2}\right)$
$\ldots . .$. Total emissions, excluding LULUCF
F-gases - Total
$\mathrm{N}_{2} \mathrm{O}$ - Energy indirect/waste
$\mathrm{N}_{2} \mathrm{O}$ - Industrial processes
$\mathrm{N}_{2} \mathrm{O}$ - Agriculture
$\mathrm{CH}_{4}-$ Waste and other
$\mathrm{CH}_{4}-$ Agriculture
$\mathrm{CH}_{4}$ - Energy
$\mathrm{CO}_{2}$ - Other (non-energy)
$\mathrm{CO}_{2}-$ International transport
$\mathrm{CO}_{2}-$ Energy

Figure 2: Global greenhouse gas emissions, per type of gas and source, including LULUCF (source with permission: Olivier and Peters [22], Trends in global $\mathrm{CO}_{2}$ and total greenhouse gas emissions: 2019 report, PBL Netherlands Environmental Assessment Agency, The Hague).

was an increase in earthworm numbers; dry summer months negatively affected epigeic species such as Dendrobaena octaedra, Dendrobaena attemsi, and Satchellius mammalis, and in wetter months, the earthworm numbers increased. Species such as Aporrectodea caliginosa and Lumbricus rubellus had a high tolerance to temperature changes. Also, the study conducted by Berman and Meshcheryakova [42] indicated a similar result: in higher temperatures with higher soil moisture, earthworm numbers increased rapidly. The study conducted by Hughes et al. [43] showed that higher air temperatures with lower soil moisture could reduce the earthworm population. The abundance of earthworms usually increases when climatic conditions are favourable, such as when the temperature is moderate and the soil moisture content is higher [17]. This abundance tends to decrease in colder climates, where the soil moisture content is lower [44].

3.2. Change in the Soil Moisture Content. The soil environment is affected directly and indirectly by drought [45]. The deficiency of precipitation or drought does not immediately affect the deeper soil layers but will reduce the water content of the upper soil layer relatively quickly [46]. The movement of soil organisms is inhibited by reduced soil water content, which hardens the soil [47] and diminishes the extent of the water film [13]. The reduction of vegetation cover by drought can cause increased temperatures, an altered microclimate on the soil surface, and reduced resource availability [48]. The biological activity and earthworm diversity of soils are reduced through increased soil temperature both directly and indirectly. The frequency and significance of droughts are increasing around the world [49], and there are only a few studies on the effects of drought on earthworms [50-54]. An increase in temperature is associated with the volatilization and degradation of organic and inorganic pollutants in the soil [18]. Thus, an increase in soil temperature increases contaminants' transportation in the ground [18].

Earthworms are only active if free water is available in the soil. They are morphologically and physiologically limited in their use of the cuticle to maintain body moisture [3]. When soils become too dry, earthworms usually lose weight, decrease their burrowing activity, and may also enter diapause or become dormant [52]. The cocoons produced by epigeic species are drought resistant although it represents an essential strategy for the survival of the species in drought-stricken areas [53] and may rapidly recover after the drought conditions end [41]. Anecic earthworms can form permanent vertical burrows in the soil, during the dry periods, can enter a diapause, and stay dormant for several months [3]. Some endogeic species such as Aporrectodea caliginosa can form nonpermanent horizontal burrows in the topsoil and form aestivation chambers covered with mucus and gut content and protect themselves against water loss [3]. The composition of earthworm community's response to droughts can likely change due to different ecological strategies these species use. Plum and Filser [54] suggested that soil's organic matter and water-holding capacity were critical factors in modifying earthworms' responses to drought conditions.

Floods, on the contrary, can cause massive changes to the soil [55] by oversaturation, and this can result in a lack of oxygen in the soil resulting in hypoxia, although the floodplains contain sediment which is very nutrient-rich making them some of the most productive ecosystems around the world [56]. The diffusion and oxygen availability of the soil are reduced during flooding, resulting in reduced soil nutrient availability since decomposition processes are halted [3]. Anaerobic conditions occur in flooded soils, which will significantly affect the composition of soil food webs, microbial biomass, and soil microbial community 
structure $[57,58]$. Plum [57] stated that flooding reduced the abundance, biomass, and diversity of all groups of soil organisms in grasslands, and an increase in temperature and flood duration increased its effects. The ability of soil invertebrates to survive depends on their behavioural, morphological, and physiological traits [57]. Singh et al. [3] reported that the abundance of earthworms was reduced in floodplain areas and that periodical flooding had speciesspecific effects on earthworm populations. Another study conducted by Bullinger-Weber et al. [59] also indicated that the absence of anecic earthworms would suggest that more erosion and sedimentation processes have taken place, and an increase in epigeic earthworms may have positive effects on the texture of the topsoil and the organic matter quality. Many earthworms can survive long periods submerged in water [3], and some earthworm species can survive in flooded soils [60]. A critical factor to consider is the period between two flooding events. The study conducted by Klok et al. [61] suggested that earthworms from a frequently flooded area mature much quicker than earthworms from a nonflooding site. Floods can also reduce earthworm populations by not giving juvenile earthworms enough time to develop into reproductive adults. Short flooding periods followed by long recovery periods can be beneficial to certain earthworm species, e.g., Lumbricus rubellus and Allolobophora chlorotica. Schütz et al. [62] and Bullinger-Weber et al. [59] suggested that they could favour epigeic earthworm species. A study conducted by Plum and Filser [54] indicated that controlled flooding should be kept short in winters and natural summer flooding should follow and that a recovery period of six months should be sufficient for the reestablishment of earthworm populations.

3.3. Soil Acidification. The soil acidification process is a gradual and continuous natural process that occurs during pedogenesis and is aided by water leaching basic cations to lower subsoil [63]. The acidification is accelerated by an increase in nitrogen and sulphur deposition which is associated with human activity [64]. Soil $\mathrm{pH}$ has a fundamental effect on the solubility and availability of potentially toxic ions, and while low $\mathrm{pH}$ (acidic) benefits free metal cations and protonated anions, higher $\mathrm{pH}$ (alkaline) will favour carbonates and hydroxyl complexes [63]. Acidification can be enhanced by high precipitation which will allow leaching of soil cations. However, the soil itself is a buffer for external $\mathrm{H}$ ions [64], and only once it exceeds its maximum capacity will the soil become acidic.

One of the main drivers of soil acidification in terrestrial environments is the accumulated nitrogen deposition, and according to Tian and Niu [65], during 2000-2010, more than $50 \mathrm{~kg} \cdot \mathrm{ha}^{-1}$ of nitrogen was accumulated in terrestrial environments. This nitrogen-induced acidification has posed a significant threat to terrestrial ecosystem functioning and species diversity. Using nitrogen fertilizers can have a variety of effects on soil acidification. The $\mathrm{NH}_{4}{ }^{+}$ions can displace base cations such as $\mathrm{Ca}^{2+}, \mathrm{Mg}^{2+}$, and $\mathrm{Na}^{+}$by binding them and making them more easily leached out of the soils, thus reducing their buffering against acidification, and therefore, when plant roots absorb the $\mathrm{NH}_{4}{ }^{+}$ions, the $\mathrm{H}^{+}$ion is released into the soil solution, and this can cause soil acidification [65]. Climate change variables such as temperature and soil moisture affect the acidification process. Higher soil moisture will allow leaching to occur more easily promoting soil acidification. Reducing the nitrogen cycles by lowered temperatures will reduce the ecosystems' ability to sequester nitrogen resulting in more acidification [63]. When precipitation is higher, it accelerates the leaching of cations, further aggravating acidification [64].

\subsection{Soil Organic Carbon (SOC) Cycling and SOC Dynamics.} The carbon cycle involves the soil, plants, and all animal life, including humans; thus, the disruption of the carbon cycle would mean disaster for all living organisms. Soil organic matter is expressed as soil organic carbon, which plays a vital role in the sorption of soil pollutants [18]. The basic processes involved in the global carbon cycle start when plants take up carbon dioxide from the atmosphere. Through photosynthesis, sunlight energy is trapped in the carbon-tocarbon bonds of organic molecules. Some of these organic molecules are used as energy sources, while carbon is returned to the atmosphere as carbon dioxide. The remaining organic materials are temporarily stored as constituents of the standing vegetation, which eventually add to the soil as plant litter or root deposition.

The productivity of the vegetation growing on the soil is related to the soil's carbon input rate, measured by the net primary production (NPP) [23]. The NPP varies with climate, land cover, species composition, and soil type and also shows seasonal variations due to its dependence on light and temperature. Smith [23] explained that, over long periods, an amount of NPP enters the soil as organic matter (decomposition of plant matter) and is converted into carbon dioxide and methane via soil heterotrophic respiration processes. Remaining carbon is referred to as net ecosystem production (NEP). Although harvesting, fires, and insect damage can also remove carbon, when combined with heterotrophic processes, they can counterbalance the terrestrial carbon dioxide input from global primary production, and residual carbon is known as net biome production (NBP), which can be positive or negative depending on whether the ecosystem is a carbon source or sink [23].

Human impact disrupts the carbon cycle balance because carbon enters the atmosphere from burning of fossil, cement production, the ocean, land use, animals, plants, and geological reservoirs through mining. The emission rate of carbon in the atmosphere remains unbalanced, and the speed at which carbon is used makes it nonrenewable, which disrupts the global carbon cycle. Climate, vegetation, parent material, topography, and time are all important factors influencing soil carbon. Soil carbon reservoir has been suggested as both a sink and a source of atmospheric carbon dioxide. It is considered a source when net decomposition exceeds carbon inputs into the soil, which could be due to human activities or global warming, and it is considered a sink when the difference between net ecosystem carbon uptake and tree growth rates exceeds the net ecosystem 
carbon uptake [66]. The degree and timing of response are determined by the amount of carbon available to respond rapidly to climate and vegetation changes, as well as the time lag between carbon fixation in plants and subsequent release to the atmosphere during decomposition.

\section{Toxicity of Pesticides towards Earthworms under Climate Change Scenarios}

4.1. The Fate of Pesticides. Climate change has left indelible imprints on the ecosystem, including extreme temperature and rainfall events, as well as an increase in atmospheric carbon dioxide $\left(\mathrm{CO}_{2}\right)$ concentrations, which may significantly affect the usage, distribution, and degradation patterns of pollutants such as pesticides [67]. Weather variables such as rainfall, temperature, and wind extremes influence pesticide fate and behaviour in the environment. It is essential to understand the environmental fate of pesticides because they are biologically active and designed to interfere with metabolic processes. The potential health risks that pesticides can have on human and environmental health need to be evaluated, after which one must take precautions to mitigate their effects. Applying pesticides to targeted areas predictably allows these chemicals to affect organisms and the environment. It is in the understanding of pesticides' physical, chemical, and biological processes that one can realize their impact on target and nontarget species. This understanding is crucial for improving pest management strategies that must have minimal adverse effects on human and environmental health. One of the most critical factors in the transport of pesticides in the soil is the sorption-desorption process because it controls the volume of pesticides available for distribution [68].

In terms of pesticide efficacy, it was widely assumed that some pesticides are more hazardous to insect pests at higher temperatures [69]. However, recent reports such as [70] discovered that chlorpyrifos decomposed more at higher temperatures, resulting in decreased mortality and oxidative damage to insect pests. This is attributable to the fact that organophosphate insecticides hydrolyze at a faster rate at higher temperatures [71]. Pesticides that undergo aqueous-phase hydrolysis, such as organophosphates, carbamates, synthetic pyrethroids, and sulfonylureas, are generally temperature-sensitive [72]. When exposed to intense sunlight, some insecticides undergo substantial photodegradation. The loss of pesticides due to volatilization is also favoured by rising temperatures [73]. Microbial activity in soil will also increase when temperature and moisture levels rise. As a result, the rate of pesticide degradation induced by soil microbes will increase. Thus, with the higher dissipation of pesticides and the climate adaptation of pests as a result of global warming, pesticides will most likely be used more frequently and at a higher application rate [72]. The uncertainties related to climate predictions make it challenging to predict the effect of climate change on pesticides. However, according to Bloomfield et al. [74], changes in temperature and seasonality and intensity of rainfall are the main drivers in pesticide fate and transport. Also, changes in land use accompanied by climate change events will substantially affect the fate of pesticides in the soil environment.

Figure 3 illustrates a simple representation of how climate change affects soil pesticides and inevitably soil organisms, specifically earthworms. Climate change is mainly caused by the greenhouse effect which is a natural effect that is accelerated by anthropogenic activities such as deforestation, burning of fossil fuels, and agricultural practices. Deforestation and agriculture can go hand in hand because according to Bennett [75], 25\% of the world's greenhouse gas emissions comes from deforestation through practices such as logging and burning of biomass, thus making agriculture one of the most important causes of deforestation. As stated above, climate change does have a great effect on the soil ecosystem, and as a result, it will influence soil organisms as well as chemicals in the ground. Several studies have found that climate change affects soil dynamics, which in turn affects pesticide toxicity to earthworms (Table 1).

\subsection{Effect of Climate Change Drivers on Pesticide Toxicity to} Earthworms. Chemical pollutants including pesticides can be altered by climate change when the climate change drivers alter the physical, chemical, and biological properties of ecosystems [85]. The impacts of climate change on pesticides may be both indirect and direct [86]. The indirect effects include changes in pesticide exposure due to the shifts in cultivation towards higher latitudes and extension of cultivation periods $[74,87]$. Potential enhancement of pesticide volatility and degradation could affect the effectiveness of pesticides against pests and thus could increase application levels for pesticides [88]. This rise in the use of pesticides may be in both quantity and scope of application [89]. In terms of direct effects, climate change can affect the decomposition and toxicity of the pesticides [86], especially in the expected temperature and precipitation alternations [88]. Degradation of the pesticide is dependent on soil moisture and temperature [90]. Soil temperature and soil moisture are key climate change drivers influencing earthworm growth, survival, fecundity, and behaviour [91] and indirectly influencing the environment of the earthworm and food availability [92]. Also, soil temperature and moisture influence most characteristics of the life cycle, such as weight, cocoon incubation time, sexual maturity initiation, reproduction, and life span. Temperature rise can speed earthworm growth and reproduction rate [78]. It has also been shown that, in Aporrectodea caliginosa earthworms, soil moisture and temperature affect biomarkers [77]. Synergistic responses have been reported in many studies dealing with the impact of soil moisture on effects of various chemicals [76, 93-95].

A study done by González-Alcaraz et al. [96] assessed how different combinations of air temperatures and soil moisture contents $\left(20^{\circ} \mathrm{C}\right.$ and $25^{\circ} \mathrm{C} ; 30 \%$ and $\left.50 \%\right)$ affected the bioaccumulation kinetics of zinc and cadmium in the earthworm species Eisenia andrei. The results of this study indicated that the earthworms accumulated zinc rapidly in contaminated soils. Still, when put in uncontaminated soil, 


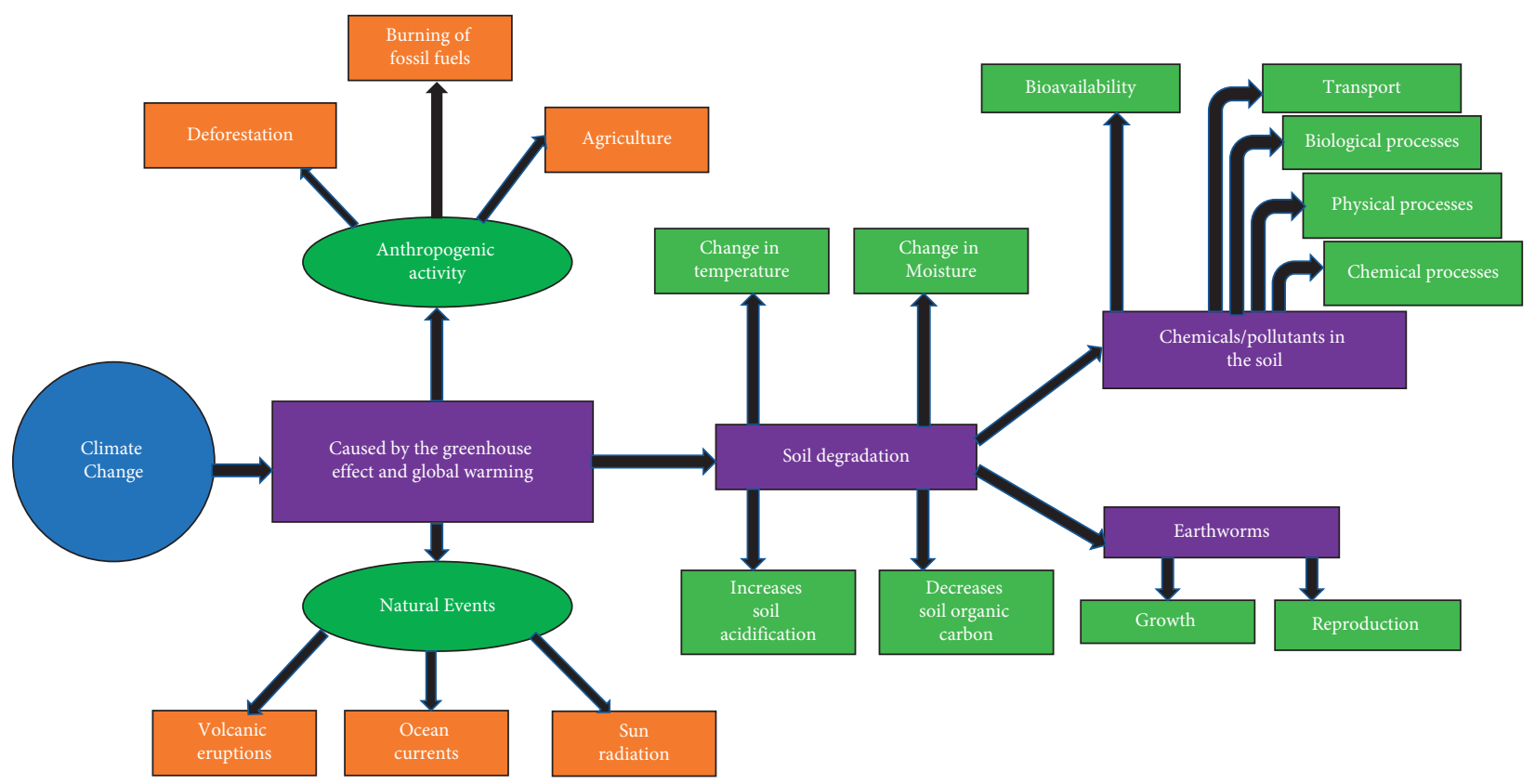

FIGURE 3: Fate and behaviour of pesticides towards earthworms under the influence of climate change.

they quickly eliminated zinc. The air temperatures of 20 and $25^{\circ} \mathrm{C}$ and the soil moisture contents of $30 \%$ and $50 \%$ had no significant impacts on zinc bioaccumulation in the earthworms. However, higher temperatures and moisture allowed cadmium to be taken up and eliminated at faster rates. The kinetics of cadmium reduced when the temperatures were higher, coupled with lower moisture contents. Analysis already performed in other studies indicates the value of ecotoxicological studies and the fact that climate change variables influence the bioavailability of pollutants in variables of soil climate change must be considered while performing these experiments. The study on Eisenia fetida species by Pelosi et al. [97] also reported how climate change can affect soil organisms as well as contaminants in the soil. According to their findings, temperature and soil moisture content influenced soil enzyme behaviour as earthworms responded to pesticides differently. The toxicity of earthworms varied when exposed to the same pesticide concentration at different temperatures, decreasing at lower temperatures and increasing at higher temperatures. This report shows that temperature variability can modify the effects of pesticides on earthworm populations. However, more research is required to better understand the complex relationship between environmental factors and the toxicity of chemicals, especially the dynamic interaction between climate change drivers and pesticide toxicity to earthworms. Toxicokinetics, bioaccumulation, and detailed life-cycle traits in earthworm toxicology research can help explain the exposure pathways taken by soil pollutants in tested species under current projected climate change scenarios which will help in better understanding the effects of these pollutants in soil and soil vertebrates with the aim of taking comprehensive mitigation strategies as well as sustainable use of agricultural pesticides.

\section{Discussion and Conclusions}

The soil ecosystem is a critical environment that provides many services. It stores carbon, provides a medium for plant growth, and serves as a natural environment for organisms. The soil environment interacts with the atmosphere and hydrosphere and provides many human civilisation materials and food to consume. Thus, the soil environment's health is crucial for human, plant, and animal life, and protecting this natural resource is essential for survival. Activities such as mining and agriculture provide a source of pollution to the soil environment. Mining disrupts the Earth's crust and displaces large volumes of soil, ruining the environment. Refining mined materials pollutes the soil and water systems. Also, large-scale agricultural practices alter the natural ecosystem, and the use of pesticides can pollute the soil and water systems through runoff and leaching. Earthworms are keystone species and are generally used in ecotoxicological studies since they interact with the soil directly and perform many functions in soil processes $[15,98-100]$. The interaction between earthworms and soil makes them a relevant species to be used in laboratory tests. There are many different earthworm species used depending on the region and tests done. Most soil ecotoxicological studies use earthworms in their tests, $[8,15,16,80,96,98,99]$ to name a few, and this gives further evidence that earthworms are a suitable species to use in these studies. Table 1 shows the results of studies on the effect of pesticides towards earthworms under climate change scenarios. Different concentrations of pesticides had different effects on various life-cycle traits of earthworms and biomarkers. When climate change variables are introduced, these same concentrations had different effects on the same tested parameters, and this will again supply more evidence for researchers to take these variables into account. 


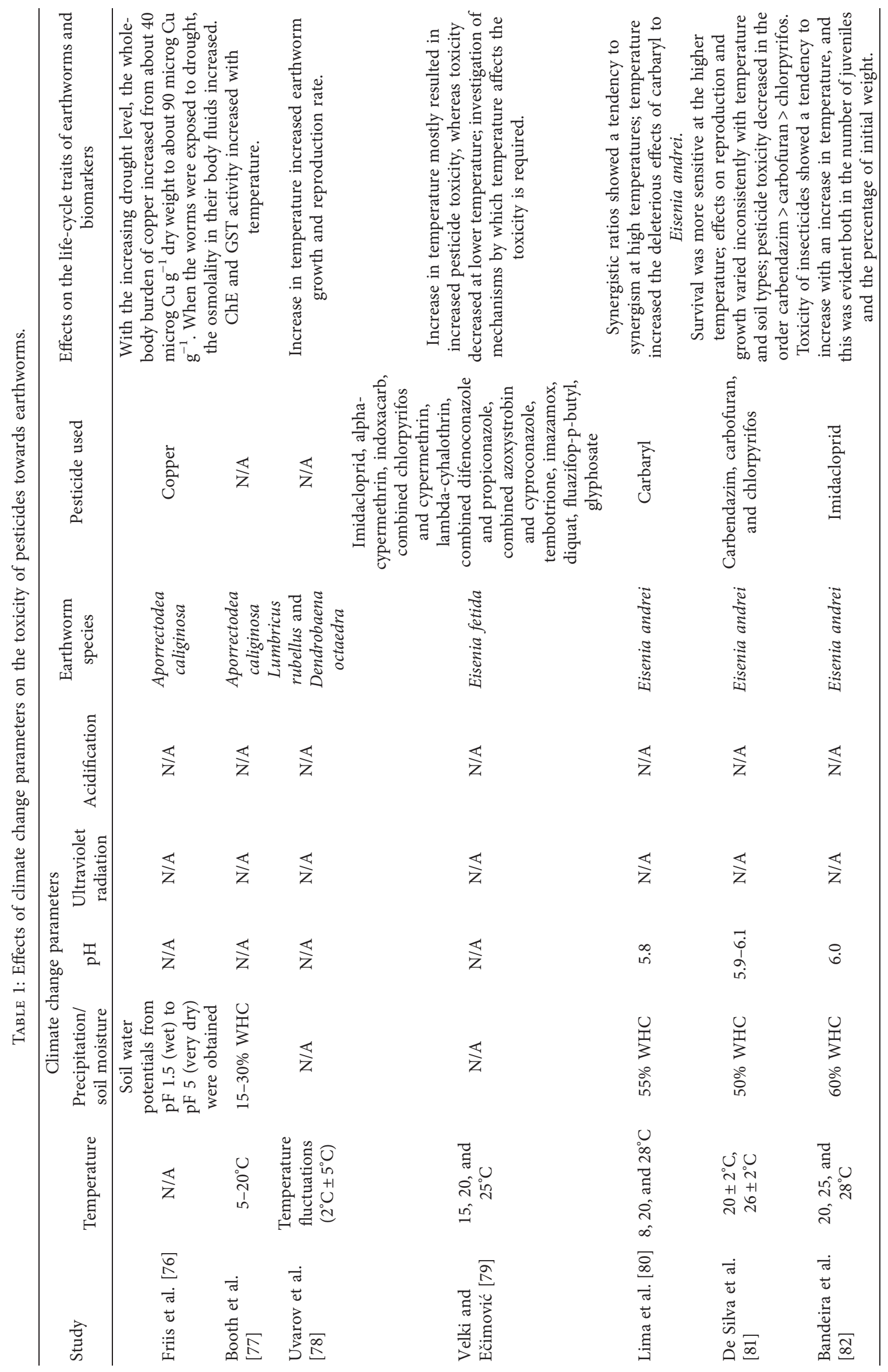




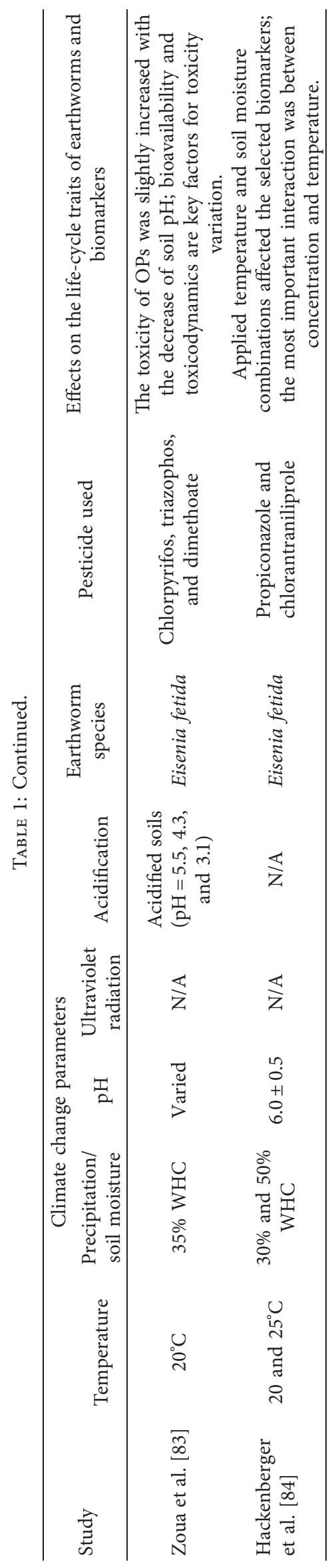


Global climate change has an impact on ecosystems worldwide. The focus of this review is on the potential effects of climate change on pesticides and their implications for earthworms in the soil ecosystem. Climate change has been shown to have a significant impact on the toxicity of pollutants in soil by altering weather patterns and natural global cycles. Previous research has found that varying temperature and moisture affect the bioavailability of pollutants in the soil ecosystem. According to many analyses from the Intergovernmental Panel on Climate Change (IPCC) report, the global temperature and other climate change drivers are becoming more severe and erratic; therefore, current research must consider environmental concerns related to climate change. Year 2019 was the second warmest year in 140 years with an increase of $0.95^{\circ} \mathrm{C}$ [22], and the reality is that global warming is affecting the human and natural world. This review highlights some of the impacts of climate change on the soil and the pollutants in the soil. Most toxicological analyses using earthworms do not take these climate change variables into account; thus, they use standard temperatures and soil moisture contents while focusing mainly on single pollutants and their effects. However, these variables undoubtedly affect the bioavailability of these pollutants in the soil. To accurately determine the effects of these pollutants in natural ecosystems, one must consider these variables. Studies such as $[22,39,40,85,101]$, to name a few, all indicate that climate change can directly affect the soil temperature and moisture. When air temperatures increase, the temperature of the soil surface increases as well, and an increase in temperature will also reduce the soil moisture. An increase in the temperature and a decrease in the soil moisture will affect the characteristics as well as the bioavailability of pollutants in the soil. Climate change also makes rainfall patterns more unpredictable, and this could lead to flooding and droughts. Both events can cause the soil moisture to become excess (flooding) or minimal (droughts). Excess water can cause leaching in the soil which will promote acidification and runoff from agricultural areas and mines which can pollute nearby areas. Droughts can reduce the vegetation cover resulting in increased soil erosion. These conditions will also affect earthworm populations as well as the bioavailability of contaminants in the soil.

Future studies must consider collecting relevant data as climate change becomes a more urgent issue. Several studies such as $[68,85,96,101-103]$ all show that other factors such as temperature and soil moisture affect the bioavailability of pesticides in the soil, thus making it essential to be taken into account and not only using the concentrations of pollutants as an endpoint.

The soil itself has capabilities to act as a buffer against pollutants as well as variables such as temperature, moisture, and acidification. The properties and make-up of the soil give it these characteristics to act as a buffer. The organic matter (carbon) in the soil can help reduce the effects of heavy metals, for instance, in the soil. The variety of microbial communities in the soil also helps to break down organic pollutants. The soil surface itself acts as a buffer to temperature changes for the lower soil levels. Certain soil types such as clay can retain water for longer periods helping with soil moisture. With regard to the acidification process, it is a slow and natural process although it is hastened by pollution. Soil is the buffer against acidification because soil buffers external $\mathrm{H}^{+}$ions, and only when the $\mathrm{H}^{+}$input exceeds the maximum of soil buffer capacity, it will cause soil acidification [64]. Soil health can maintain the health of animals, plants, humans, and the environment [19], making it a vital system that needs to be monitored and protected. Soil pollutants such as heavy metals, organic contaminants, and persistent organic pollutants have been found in soil ecosystems and pose a threat to animal, human, and plant health [18]. The possibility of these pollutants affecting human and animal life is increasing with increasing pollution. Climate change effects are becoming more and more evident. The impact they have on soil pollutants is seen in ecosystems worldwide, making it a critical variable when performing ecotoxicological research. More research is needed to obtain adequate data on the interaction of environmental factors such as the temperature and moisture and other extreme climate change drivers. This has become more relevant with the acceleration of global climate and to enable relevant key climate regulatory authorities to implement laws to mitigate and manage the effects of the soil pollution on ecosystem health.

\section{Data Availability}

The data used to support the findings of this study are available from the corresponding author upon request.

\section{Conflicts of Interest}

The authors declare that there are no conflicts of interest.

\section{Acknowledgments}

The authors are thankful to the Unit for Environmental Sciences and Management, North-West University, South Africa, for their support.

\section{References}

[1] Intergovernmental Panel on Climate Change (IPCC), Confidence and Likelihood in the IPCC Fifth Assessment Report, IPCC, Geneva, Switzerland, 2013.

[2] B. Akinsanya, O. E. Ade-Ademilua, O. A. Idris, U. D. Ukwa, and K. J. Saliu, "Toxicological evaluation of plant crude extracts on helminth parasites of Clarias gariepinus using host low observed effect concentration (LOEC). Egypt," Journal of Aquatic Biology and Fisheries, vol. 20, pp. 69-77, 2016.

[3] J. Singh, M. Schädler, W. Demetrio, G. G. Brown, and N. Eisenhauer, "Climate change effects on earthworms-a review," Soil Organisms, vol. 91, pp. 113-137, 2019.

[4] R. D. Bardgett and W. H. Van Der Putten, "Belowground biodiversity and ecosystem functioning," Nature, vol. 515, 2014.

[5] M. Blouin, M. E. Hodson, E. A. Delgado et al., "A review of earthworm impact on soil function and ecosystem services," European Journal of Soil Science, vol. 64, pp. 161-182, 2013. 
[6] P. Jouquet, E. Blanchart, and Y. Capowiez, "Utilization of earthworms and termites for the restoration of ecosystem functioning," Applied Soil Ecology, vol. .73, 2014.

[7] D. H. Wall, U. N. Nielsen, and J. Six, "Soil biodiversity and human health," Nature, vol. 528, 2015.

[8] M. T. Jubileus, P. D. Theron, L. Van Rensburg, and M. S. Maboeta, "Utilizing Eisenia andrei to assess the ecotoxicity of platinum mine tailings disposal facilities," Ecotoxicology, vol. 22, pp. 331-338, 2013.

[9] M. S. Maboeta, O. G. Oladipo, and S. M. Botha, "Ecotoxicity of mine tailings: unrehabilitated versus rehabilitated," Bulletin of Environmental Contamination and Toxicology, vol. 100, pp. 702-707, 2018.

[10] B. Mcguirk, P. Theron, and M. Maboeta, "African Zoology the effects of different gold mine tailings on growth, reproduction and avoidance-behaviour of earthworms," Taylor \& Francis, vol. 55, pp. 35-42, 2020.

[11] G. Gelybó, E. Tóth, C. Farkas, Á. Horel, I. Kása, and Z. Bakacsi, "Potential impacts of climate change on soil properties," AK Journals, vol. 67, pp. 121-141, 2018.

[12] C. S. Csuzdi, Earthworm Species, a Searchable Database, Opusc. Zool., Budapest, Hungary, 2012.

[13] D. C. Coleman, M. A. Callaham, and D. Crossley Jr, Fundamentals of Soil Ecology, Academic Press, Cambridge, MA, USA, 2018.

[14] H.-C. Fründ, U. Graefe, and S. Tischer, Earthworms as Bioindicators of Soil Quality, Springer, London, UK, 2011.

[15] M. Maboeta and T. Fouche, "Utilizing an earthworm bioassay (eisenia andrei) to assess a South African soil screening value with regards to effects from a copper manufacturing industry," Bulletin of Environmental Contamination and Toxicology, vol. 93, pp. 322-326, 2014.

[16] O. G. Oladipo, A. F. Burt, and M. S. Maboeta, "Effect of Bacillus cereus on the ecotoxicity of metal-based fungicide spiked soils: earthworm bioassay," Ecotoxicology, vol. 28, pp. 37-47, 2019.

[17] H. R. P. Phillips, C. A. Guerra, M. L. C. Bartz et al., "Global distribution of earthworm diversity," Science, vol. 366, pp. 480-485, 2019.

[18] B. Biswas, F. Qi, J. K. Biswas, A. Wijayawardena, M. A. I. Khan, and R. Naidu, "The fate of chemical pollutants with soil properties and processes in the climate change paradigm-a review," Soil System, vol. 2, 2018.

[19] A. Patil and M. Lamnganbi, "Impact of climate change on soil biodiversity-a review," Agricultural Reviews, vol. 33, pp. 283-292, 2012.

[20] Intergovernmental Panel on Climate Change (IPCC), Global Warming of $1.5^{\circ} \mathrm{C}$, An Ipcc Special Report On The Impacts Of Global Warming of $1.5^{\circ} \mathrm{C}$ Above Pre-Industrial Levels And Related Global Greenhouse Gas Emission Pathways, In The Context Of Strengthening The Global Response To The Threat Of Climate Change, Sustainable Development, And Efforts To Eradicate Poverty, IPCC, Incheon, Republic of Korea, 2018.

[21] D. Kweku, O. Bismark, A. Maxwell et al., "Greenhouse effect: greenhouse gases and their impact on global warming," Journal of Scientific Research and Reports, vol. 17, pp. 1-9, 2018.

[22] J. G. J. Olivier and J. A. H. W. Peters, Trends in Global $\mathrm{CO}_{2}$ and Total Greenhouse Gas Emissions: Report 2019, PBL Netherlands Environ. Assess. Agency, Den Haag, Netherland, 2020

[23] P. Smith, "Land use change and soil organic carbon dynamics," Nutrient Cycling in Agroecosystems, vol. 81, pp. 169-178, 2008.
[24] S. Marhan, J. Auber, and C. Poll, "Additive effects of earthworms, nitrogen-rich litter and elevated soil temperature on $\mathrm{N}_{2} \mathrm{O}$ emission and nitrate leaching from an arable soil," Applied Soil Ecology, vol. 86, pp. 55-61, 2015.

[25] K. A. Smith, T. Ball, F. Conen, K. E. Dobbie, and A. Rey, "Exchange of greenhouse gases between soil and atmosphere: interactions of soil physical factors and biological processes," European Journal of Soil Science, vol. 69, pp. 2-4, 2003.

[26] J. G. J. Olivier, K. M. Schure, and J. A. H. W. Peters, Trends in Global $\mathrm{CO}_{2}$ and Total Greenhouse Gas Emissions Summary of the 2017 Report, PBL Netherlands Environ. Assess. Agency, Den Haag, Netherland, 2017.

[27] S. C. Chuang, W. S. Lai, and J. H. Chen, "Influence of ultraviolet radiation on selected physiological responses of earthworms," Journal of Experimental Biology, vol. 209, pp. 4304-4312, 2006.

[28] P. Formánek, K. Rejšek, and V. Vranová, "Effect of elevated $\mathrm{CO} \mathrm{O}$ and UV radiation on soils," Science World Journal, vol. 2014, Article ID 730149, 8 pages, 2014.

[29] J. Wang, S. Yang, B. Zhang et al., "Temporal dynamics of ultraviolet radiation impacts on litter decomposition in a semi-arid ecosystem," Plant and Soil, vol. 419, pp. 71-81, 2017.

[30] C. Bellard, C. Bertelsmeier, P. Leadley, W. Thuiller, F. Courchamp, and J. Fourier, "Impacts of climate change on the future of biodiversity," Ecology Letters, vol. 15, no. 4, pp. 365-377, 2012.

[31] D. A. Wardle, R. D. Bardgett, J. N. Klironomos, H. Setälä, W. H. Van Der Putten, and D. H. Wall, "Ecological linkages between aboveground and belowground biota," Science, vol. 80, 2004.

[32] N. Eisenhauer, A. Bonn, and C. Guerra, "Recognizing the quiet extinction of invertebrates," Nature Communications, vol. 10, 2019.

[33] E. K. Cameron, I. S. Martins, P. Lavelle et al., "Global mismatches in aboveground and belowground biodiversity," Conservation Biology, vol. 33, pp. 1187-1192, 2019.

[34] S. Veresoglou, J. Halley, and M. Rillig, "Extinction risk of soil biota," Nature Communications, vol. 6, p. 8862, 2015.

[35] J. M. Perreault and J. K. Whalen, "Earthworm burrowing in laboratory microcosms as influenced by soil temperature and moisture," Handbook of Environmental Chemistry, vol. 5, pp. 397-403, 2006.

[36] J. T. Staley, S. R. Mortimer, and M. D. Morecroft, "Drought impacts on above-belowground interactions: do effects differ between annual and perennial host species?" Basic and Applied Ecology, vol. 9, pp. 673-681, 2008.

[37] L. A. Wever, T. J. Lysyk, and M. J. Clapperton, "The influence of soil moisture and temperature on the survival, aestivation, growth and development of juvenile Aporrectodea tuberculata (Eisen) (Lumbricidae)," Pedobiologia, vol. 45, pp. 121-133, 2001.

[38] P. Moreau-Valancogne, M. Bertrand, M. Holmstrup, and J. Roger-Estrade, "Integration of thermal time and hydrotime models to describe the development and growth of temperate earthworms," Soil Biology and Biochemistry, vol. 63 , pp. 50-60, 2013

[39] I.-C. Chen, J. K. Hill, R. Ohlemüller, D. B. Roy, and C. D. Thomas, "Rapid range shifts of species associated with high levels of climate warming," Science, vol. 3, pp. 10241026, 2011.

[40] S. E. Gilman, M. C. Urban, J. Tewksbury, G. W. Gilchrist, and R. D. Holt, "A framework for community interactions under 
climate change," Trends in Ecology \& Evolution, vol. 25, pp. 325-331, 2010.

[41] P. Eggleton, K. Inward, J. Smith, D. T. Jones, and E. Sherlock, "A six year study of earthworm (Lumbricidae) populations in pasture woodland in southern England shows their responses to soil temperature and soil moisture," Soil Biology and Biochemistry, vol. 41, pp. 1857-1865, 2009.

[42] D. I. Berman and E. N. Meshcheryakova, "Ranges and cold hardiness of two earthworm subspecies (Eisenia nordenskioldi, Lumbricidae, Oligochaeta)," Biology Bulletin, vol. 40, no. 9, pp. 719-727, 2013.

[43] F. M. Hughes, J. E. Côrtes-Figueira, and M. A. Drumond, "Anticipating the response of the brazilian giant earthworm (Rhinodrilus alatus) to climate change: implications for its traditional use," Anais da Academia Brasileira de Ciencias, vol. 91, 2019.

[44] C. L. Walsh and J. L. Johnson-Maynard, "Earthworm distribution and density across a climatic gradient within the Inland Pacific Northwest cereal production region," Applied Soil Ecology, vol. 104, pp. 104-110, 2016.

[45] D. R. Coyle, U. J. Nagendra, M. K. Taylor et al., "Soil fauna responses to natural disturbances, invasive species, and global climate change: current state of the science and a call to action," Soil Biology and Biochemistry, vol. 110, 2017.

[46] D. C. Nepstad, "The effects of partial throughfall exclusion on canopy processes, aboveground production, and biogeochemistry of an Amazon forest," Journal of Geophysical Research, vol. 107, 2002.

[47] P. T. Q. Anh, T. Gomi, L. H. MacDonald, S. Mizugaki, P. Van Khoa, and T. Furuichi, "Linkages among land use, macronutrient levels, and soil erosion in northern Vietnam: a plot-scale study," Geoderma, vol. 232, pp. 352-362, 2014.

[48] J. Franklin, M. J. Serra-Diaz, D. A. Sypard, and M. H. Regan, "Global change and terrestrial plant community dynamics," PNAS, vol. 113, pp. 3725-3734, 2016.

[49] A. Dai, "Erratum: increasing drought under global warming in observations and models," Nature Climate Change, vol. 3, 2013.

[50] M. Holmstrup, S. Slotsbo, P. G. Henriksen, and M. Bayley, "Earthworms accumulate alanine in response to drought," Comparative Biochemistry and Physiology, A: Molecular and Integrative Physiology, vol. 199, pp. 8-13, 2016.

[51] A. Morón-Ríos, M. Á. Rodríguez, L. Pérez-Camacho, and S. Rebollo, "Effects of seasonal grazing and precipitation regime on the soil macroinvertebrates of a mediterranean old-field," European Journal of Soil Biology, vol. 46, pp. 91-96, 2010.

[52] O. J. Owojori and A. J. Reinecke, "Effects of natural (flooding and drought) and anthropogenic (copper and salinity) stressors on the earthworm Aporrectodea caliginosa under field conditions," Applied Soil Ecology, vol. 44, pp. 156-163, 2010.

[53] C. R. Petersen, M. Holmstrup, A. Malmendal, M. Bayley, and J. Overgaard, "Slow desiccation improves dehydration tolerance and accumulation of compatible osmolytes in earthworm cocoons (Dendrobaena octaedra Savigny)," Journal of Experimental Biology, vol. 211, pp. 1903-1910, 2008.

[54] N. M. Plum and J. Filser, "Floods and drought: response of earthworms and potworms (Oligochaeta: lumbricidae, Enchytraeidae) to hydrological extremes in wet grassland," Pedobiologia, vol. 49, pp. 443-453, 2005.

[55] Q. Zhang, E. J. W. Visser, H. De Kroon, and H. Huber, "Life cycle stage and water depth affect flooding-induced adventitious root formation in the terrestrial species Solanum dulcamara," Annals of Botany, vol. 116, pp. 279-290, 2015.

[56] K. Tockner and J. A. Stanford, "Review of: riverine flood plains: present state and future trends," Environmental Conservation, vol. 29, 2002.

[57] N. Plum, "Terrestrial invertebrates in flooded grassland: a literature review," Wetlands, vol. 25, 2005.

[58] I. M. Unger, A. C. Kennedy, and R. M. Muzika, "Flooding effects on soil microbial communities," Applied Soil Ecology, vol. 42, pp. 1-8, 2009.

[59] G. Bullinger-Weber, C. Guenat, C. Salomé, J. M. Gobat, and R. C. Le Bayon, "Impact of flood deposits on earthworm communities in alder forests from a subalpine floodplain (Kandersteg, Switzerland)," European Journal of Soil Biology, vol. 49, pp. 5-11, 2012.

[60] M. I. Zorn, C. A. M. Van Gestel, E. Morrien, M. Wagenaar, and H. Eijsackers, "Flooding responses of three earthworm species, Allolobophora chlorotica, Aporrectodea caliginosa and Lumbricus rubellus, in a laboratory-controlled environment," Soil Biology and Biochemistry, vol. 40, pp. 587593, 2008.

[61] C. Klok, M. Zorn, J. E. Koolhaas, H. J. P. Eijsackers, and C. A. M. Van Gestel, "Does reproductive plasticity in Lumbricus rubellus improve the recovery of populations in frequently inundated river floodplains?" Soil Biology and Biochemistry, vol. 38, pp. 611-618, 2006.

[62] K. Schütz, P. Nagel, A. Dill, and S. Scheu, "Structure and functioning of earthworm communities in woodland flooding systems used for drinking water production," $A p$ plied Soil Ecology, vol. 39, pp. 342-351, 2008.

[63] Z. Rengel, "Soil pH, soil health and climate change," Soil Biology, vol. 29, pp. 66-85, 2011.

[64] C. Meng, D. Tian, H. Zeng, Z. Li, C. Yi, and S. Niu, "Global soil acidification impacts on belowground processes," Environmental Research Letters, vol. 14, 2019.

[65] D. Tian and S. Niu, "A global analysis of soil acidification caused by nitrogen addition," Environmental Research Letters, vol. 10, 2015.

[66] S. E. Trumbore, "Potential responses of soil organic carbon to global environmental change," National Academic Sciences, vol. 16, 1997.

[67] A. Saha, R. K. Rakesh Kumar Ghosh, and B. B. Basak, Fate and Behavior of Pesticides and Their Effect on Soil Biological Properties under Climate Change Scenario, Springer, London, UK, 2019.

[68] P. J. Rice, P. J. Rice, E. L. Arthur, and A. C. Barefoot, "Advances in pesticide environmental fate and exposure assessments," Journal of Agricultural and Food Chemistry, vol. 55, pp. 5367-5376, 2007.

[69] P. D. Noyes and S. C. Lema, "Forecasting the impacts of chemical pollution and climate change interactions on the health of wildlife," Current Zoology, vol. 61, no. 4, pp. 669-689, 2015.

[70] L. O. de Beeck, J. Verheyen, and R. Stoks, "Integrating both interaction pathways between warming and pesticide exposure on upper thermal tolerance in high-and low-latitude populations of an aquatic insect," Environmental Pollution, vol. 224, pp. 714-721, 2017.

[71] M. J. Hooper, G. T. Ankley, D. A. Cristol, L. A. Maryoung, P. D. Noyes, and K. E. Pinkerton, "Interactions between chemical and climate stressors: a role for mechanistic toxicology in assessing climate change risks," Environmental Toxicology \& Chemistry, vol. 32, no. 1, pp. 32-48, 2013. 
[72] P. P. Choudhury and S. Saha, "Dynamics of pesticides under changing climatic scenario," Environmental Monitoring and Assessment, vol. 192, p. 814, 2020.

[73] P. O. Otieno, P. O. Owuor, J. O. Lalah, G. Pfister, and K. W. Schramm, "Impacts of climate-induced changes on the distribution of pesticides residues in water and sediment of Lake Naivasha, Kenya," Environmental Monitoring and Assessment, vol. 185, no. 3, pp. 2723-2733, 2013.

[74] J. P. Bloomfield, R. J. Williams, D. C. Gooddy, J. N. Cape, and P. Guha, "Impacts of climate change on the fate and behaviour of pesticides in surface and groundwater-a UK perspective," The Science of the Total Environment, vol. 369, no. 1-3, pp. 163-177, 2006.

[75] L. Bennett, Deforestation and Climate Change, Deforestation and Climate Change, Climate Institude, Washington, DC, USA, 2017.

[76] K. Friis, C. Damgaard, and M. Holmstrup, "Sublethal soil copper concentrations increase mortality in the earthworm Aporrectodea caliginosa during drought," Ecotoxicology and Environmental Safety, vol. 57, pp. 65-73, 2004.

[77] L. Booth, V. Heppelthwaite, and A. Mc Glinchy, "The effect of environmental parameters on growth cholinesterase activity and glutathione S-transferase activity in the earthworm (Aporrectodea caliginosa)," Biomarkers, vol. 5, no. 1, pp. 46-55, 2000.

[78] A. V. Uvarov, A. V. Tiunov, and S. Scheu, "Effects of seasonal and diurnal temperature fluctuations on population dynamics of two epigeic earthworm species in forest soil," Soil Biology and Biochemistry, vol. 43, pp. 559-570, 2011.

[79] M. Velki and S. Ečimović, "Changes in exposure temperature lead to changes in pesticide toxicity to earthworms: a preliminary study," Environmental Toxicology and Pharmacology, vol. 40, pp. 774-784, 2015.

[80] M. P. R. Lima, D. N. Cardoso, A. M. V. M. Soares, and S. Loureiro, "Carbaryl toxicity prediction to soil organisms under high and low temperature regimes," Ecotoxicology and Environmental Safety, vol. 114, 2015.

[81] P. M. C. S. De Silva, A. Pathiratne, and C. A. M. van Gestel, "Influence of temperature and soil type on the toxicity of three pesticides to Eisenia andrei," Chemosphere, vol. 76, pp. 1410-1415, 2009.

[82] F. O. Bandeira, P. R. Lopes Alves, T. B. Hennig, T. Toniolo, T. Natal-da-Luz, and D. Baretta, "Effect of temperature on the toxicity of imidacloprid to Eisenia andrei and Folsomia candida in tropical soils," Environmental Pollution, vol. 267, Article ID 115565, 2020.

[83] X. Zoua, X. Xiaoa, H. Zhoua et al., "Effects of soil acidification on the toxicity of organophosphorus pesticide on Eisenia fetida and its mechanism," Journal of Hazardous Materials, vol. 359, pp. 365-372, 2018.

[84] D. K. Hackenberger, G. Palijan, Z. Lončarić, O. J. Glavaš, and B. K. Hackenberger, "Influence of soil temperature and moisture on biochemical biomarkers in earthworm and microbial activity after exposure to propiconazole and chlorantraniliprole," Ecotoxicology and Environmental Safety, vol. 148, pp. 480-489, 2018.

[85] M. N. González-Alcaraz and C. van Gestel, Climate Change Effects on Enchytraeid Performance in Metal-Polluted Soils Explained from Changes in Metal Bioavailability and Bioaccumulation, Elsevier, Amsterdam, Netherlands, 2015.

[86] M. Kattwinkel, I.-V. Kiihne, K. Foit, and M. Liess, "Climate change, agricultural insecticide exposure, and risk for freshwater communities," Ecological Applications, vol. 21, no. 6, pp. 2068-2081, 2011.
[87] F. N. Tubiello, C. Rosenzweig, R. A. Goldberg, S. Jagtap, and J. W. Jones, "Effects of climate change on US crop production: simulation results using two different GCM scenarios. Part I: wheat, potato, maize, and citrus," Climate Research, vol. 20, no. 3, pp. 259-270, 2002.

[88] P. D. Noyes, M. K. McElwee, H. D. Miller et al., "The toxicology of climate change: environmental contaminants in a warming world," Environment International, vol. 35, pp. 971-986, 2009.

[89] N. G. Koleva and U. A. Schneider, "The impact of climate change on the external cost of pesticide applications in US agriculture," International Journal of Agricultural Sustainability, vol. 7, pp. 203-216, 2009.

[90] R. Kookana, G. Holz, C. Barnes, K. Bubb, R. R. Fremlin, and B. Boardman, "Impact of climatic and soil conditions on environmental fate of atrazine used under plantation forestry in Australia," Journal of Environmental Management, vol. 91, pp. 2649-2656, 2010.

[91] C. A. Edwards and P. J. Bohlen, Biology and Ecology of Earthworms, p. 426, 3rd edition, Springer, London, UK, 1996.

[92] J. P. Curry, "Factors affecting the abundance of earthworms in soils," in Earthworm Ecology, CRC Press, Boca Raton, FL, USA, 2004.

[93] A. Bindesbøl, M. Holmstrup, C. Damgaard, and M. Bayley, "Stress synergy between environmentally realistic levels of copper and frost in the earthworm Dendrobaena noctaedra," Environmental Toxicology \& Chemistry, vol. 24, pp. 14621467, 2005.

[94] M. P. R. Lima, A. M. V. M. Soares, and S. Loureiro, "Combined effects of soil moisture and carbaryl to earthworms and plants: simulation of flood and drought events," Environmental Pollution, vol. 159, pp. 1844-1851, 2011.

[95] S. M. Long, F. Reichenberg, L. J. Lister et al., "Combined chemical (Fluoranthene) and drought effects on Lumbricus rubellus demonstrate the applicability of the independent action model for multiple stressor assessment," Environmental Toxicology \& Chemistry, vol. 28, pp. 629-636, 2009.

[96] M. N. González-Alcaraz, S. Loureiro, and C. A. M. van Gestel, "Toxicokinetics of $\mathrm{Zn}$ and $\mathrm{Cd}$ in the earthworm Eisenia andrei exposed to metal-contaminated soils under different combinations of air temperature and soil moisture content," Chemosphere, vol. 197, pp. 26-32, 2018.

[97] C. Pelosi, S. Barot, Y. Capowiez et al., "Pesticides and earthworms," A review on Agronomy for Sustainable Development, vol. 34, pp. 199-228, 2014.

[98] M. S. Maboeta, S. A. Reinecke, and A. J. Reinecke, "The relation between lysosomal biomarker and population responses in a field population of Microchaetus sp. (Oligochaeta) exposed to the fungicide copper oxychloride," Ecotoxicology and Environmental Safety, vol. 52, pp. 280287, 2002.

[99] S. A. Reinecke, B. Helling, and A. J. Reinecke, "Lysosomal response of earthworm (Eisenia fetida) coelomocytes to the fungicide copper oxychloride and relation to life-cycle parameters," Environmental Toxicology \& Chemistry, vol. 21, pp. 1026-1031, 2002.

[100] S. A. Reinecke and A. J. Reinecke, "The comet assay as biomarker of heavy metal genotoxicity in earthworms," Archives of Environmental Contamination and Toxicology, vol. 46, pp. 208-215, 2004.

[101] M. N. González-Alcaraz and C. A. M. Van Gestel, "Metal/ metalloid (As, $\mathrm{Cd}$ and $\mathrm{Zn}$ ) bioaccumulation in the 
earthworm Eisenia andrei under different scenarios of climate change," Environmental Pollution, vol. 215, pp. 178186, 2016.

[102] I. Giska, C. A. M. Van Gestel, B. Skip, and R. Laskowski, "Toxicokinetics of metals in the earthworm Lumbricus rubellus exposed to natural polluted soils-relevance of laboratory tests to the field situation," Environmental Pollution, vol. 190, pp. 123-132, 2014.

[103] B.-T. Lee and K.-W. Kim, "Toxicokinetics and biotransformation of as (III) and as (V) in Eiseniaï ¿ifetida," Human and Ecological Risk Assessment: An International Journal, vol. 19, pp. 792-806, 2013. 